\title{
UPAYA MENINGKATKAN HASIL BELAJAR AKIDAH AKHLAK MELALUI METODE ROLE PLAYING PADA SISWA KELAS VIII DI MTsN KOTA BOGOR
}

\author{
Maria Ulfah $^{\text {a) }}$, Santi Lisnawati ${ }^{\text {a) }}$ \\ ${ }^{a)}$ Universitas Ibn Khaldun,Bogor, Indonesia \\ e-mail korespondensi : ulfahmaria830@gmail.com
}

diterima: 26 Oktober 2018; direvisi: 10 Januari 2019; disetujui: 05 Februari 2019

\begin{abstract}
The purpose of this is to determine the improvement of students' learning outcomes in class VIII MTsN Bogor, taught using the Role Playing method. The form of research used is Classroom Action Research. Presented in the third cycle, each cycle consists of 4 stages, planning, implementing, observing and refining. Data colection tecniques in the form of test questions with 10 items formed essays and indirect observation activities. The result of the study are obtained from the average value of student learning out comes cycle I was 52 with a percentage of $42,42 \%$ and increased in cycle II to $66,5 \%$ with a percentage of $78,78 \%$ and incerseted in cycle III to 66,5 with a percentage of $78.78 \%$.
\end{abstract}

Keywords: Akidah Akhlak, Learning Outcomes, Role Playing.

\section{PENDAHULUAN}

Pendidikan adalah suatu hal yang tidak dapat dipisahkan dari kehidupan manusia sebab pendidikan merupakan sarana pembentuk kepribadian. Pendidikan salah satu pengajaran diselenggarakan di sekolah sebagai lembaga pendidikan formal. Dan pendidikan merupakan upaya yang dapat mempercepat pengembangan potensi manusia untuk mampu mengembangkan tugas yang dibebankan padanya, karena hanya manusia yang dapat dididik dan mendidik (Sa'ud [1]).

Proses belajar terjadi karena adanya interaksi individu dengan lingkungannya. Salah satu petanda bahwa seseorang telah belajar adalah adanya perubahan tingkah laku atau akhlak dalam dirinya. Ada dua indikator yang dijadikan tolak ukur keberhasilan suatu proses pembelajaran. Dua indikator tersebut adalah adanya partisipasi peserta didik dalam proses pembelajaran dan ketercapaian peserta didik terhadap kompetensi pembelajaran sebagaimana yang ditentukan.

Pendidikan hal yang sangat kompleks, dan pendidikan menjadi salah satu dari tolak ukur kemajuan sebuah negara. Oleh karena itu keberhasilan belajar mengajar mampu mengoptimalkan segala potensi yang dimiliki, salah satunya adalah peserta didik (Sadiman [2]).

Hasil belajar siswa adalah kemampuan yang diperoleh anak setelah melalui kegiatan belajar. Karena belajar itu sendiri merupakan suatu proses dari seseorang yang berusaha untuk memperoleh suatu bentuk perubahan prilaku yang relatif menetap. Dalam kegiatan pembelajaran atau kegiatan instruksional, biasanya guru menetapkan tujuan belajar. Siswa yang berhasil dalam belajar adalah yang berhasil mencapai tujuan-tujuan pembelajaran (Susanto [3])

Jadi, dapat disimpulkan bahwa seseorang telah belajar kalau terdapat perubahan tingkah laku dalam dirinya. Sebagai tindakan, maka belajar yang dialami oleh siswa sendiri. Siswa adalah penentu terjadinya atau tidak terjadinya proses belajar (Dimyati [4])
Sekolah merupakan faktor yang paling penting dalam memberi pengaruh terhadap pembentukan akhlak seseorang (Usman [5]) Bahkan didalam ajaran Islam ditegaskan bahwa salah satu ciri manusia muslim adalah aktif melakukan ibadah yang wajib dilaksanakan oleh setiap muslim, untuk mencapai tujuan tersebut maka perlu diusahakan agar pendidikan agama dipersiapkan dengan matang.

Kurangnya minat peserta didik dalam mengikuti pembelajaran menjadi penyebab masalah rendahnya hasil belajar siswa. Hal ini disebabkan antara lain karena pembawaan materi yang kurang menarik dan terjadi ketidak sesuaian metode yang dipakai guru dalam pembelajaran.

Menyikapi masalah tersebut, perlu diterapkan dan dikembangkan sebuah metode pembelajaran yang efektif yang mengikuti sertakan peserta didik sehingga peserta didik dapat memperoleh pengalaman-pengalaman belajar yang lebih kongkret. Sebuah pembelajaran yang kongkret yang melibatkan peran aktif peserta didik mampu mendorong peserta didik untuk menerima pesan dan nilai-nilai yang disampaikan, salah satunya dengan menggunakan metode Role Playing.

Berdasarkan permasalahan tersebut diatas, maka peneliti bermaksud untuk mencari tahu dengan melakukan penelitian tindakan kelas dengan menerapkan metode Role Playing untuk meningkatkan hasil belajar Akidah Akhlak pada siswa kelas VIII di MTsN Bogor.

\section{METODE PENELITIAN}

Bentuk penelitian yang digunakan adalah penelitian tindakan kelas (Classroom Action Research). Metode Penelitian Tindakan Kelas (PTK) yang digunakan adalah menerapkan metode role playing untuk meningkatkan hasil belajar siswa. Subjek yang ditetapkan dalam penelitian ini adalah kelas VIII MTsN Kota Bogor tahun ajaran 2017/2018 yang berjumalh 38 siswa (Arikunto [6])

PTK merupakan suatu kegiatan yang dilakukan oleh guru atau bersama-sama dengan orang lain yang bertujuan 
untuk memperbaiki atau meningkatkan mutu proses pembelajaran di kelasnya. (Ekawarna, 20

Penelitian ini merupakan penelitian tindakan kelas yang dilaksanakan dalam beberapa siklus. Selain tahap pra siklus setiap siklus meliputi 4 (empat) tahap kegiatan, yaitu tahap perencanaan, tahap pelaksanaan tindakan, tahap pengamatan dan tahap refleksi.(1) perencanaan yang dimulai dengan merancang skenario pembelajaran yang berisikan materi akidah akhlak menggunakan metode role playing, dan lembar observasi, (2) Pelaksanaan Tindakan pembelajaran dengan menerapkan metode role playing dengan skenario yang telah disiapkan, (3) Pelaksanaan Observasi dilakukan untuk mengetahui dan memperoleh gambaran lengkap secara objektif tentang perkembangan proses dan pengaruh tindakan yang dipilih terhadap kondisi kelas dalam bentuk data. (4) Refleksi merupakan uraian tentang prosedur analisis terhadap hasil penelitian dan refleksi berkaitan dengan proses dan dampak tindakan perbaikan yang dilaksanakan serta kriteria dan rencana pada tindakan pada siklus berikutnya (Abidin [7]) Siklus I, tindakan dilakukan dengan disertai dengan lembar observasi untuk melihat pengaruh tindakan yang dilakukan dalam memberikan peningkatan hasil belajar dan aktivitas siswa. Tahap refleksi, pengajar dan peneliti berdiskusi tentang hasil yang diperoleh dan memutuskan apakah siklus dilanjutkan atau tidak. Tiap siklus diakhiri dengan test untuk melihat akhir belajar. Siklus I belum berhasil maka dilanjutkan ke siklus II dan dilanjutkan sampai ke siklus III.

\section{HASIL DAN PEMBAHASAN}

Mts Negeri Kota Bogor adalah sekolah setingkat SLTP yang bernaung dibawah pembinaan serta bertanggung jawab kepada Kementrian Agama Kota Bogor. MTs Negeri Kota Bogor adalah pecahan dari PGAN 6 tahun Bogor yaitu kelas 1, 2 dan 3 MTs Negeri Kota Bogor mulai beroprasional pada tanggal 31 Maret 1979 dengan 26 orang (Guru dan Staf TU). Mengelola 9 kelas dengan jumlah siswa 450 siswa. Mulai tahun ajaran 1995/1996 MTs Negeri Kota Bogor pindah dari Jl. Pajajaran ke tempat yang baru di Bangbarung Tegal Gundil.

Sebelum melaksanakan pembelajaran Siklus I, Siklus II dan Siklus III dengan menerapkan metode role playing pada pemebelajaran di kelas VIII MTsN Kota Bogor. Peneliti melakukakan wawancara terhadap guru mata pelajaran Akidah Akhlak untuk mengetahui bagaimana proses pembalajaran.

Penelitian Siklus I pertemuan pertama dilaksanakan pada hari kamis tanggal 20 September 2018. Dipertemuan ini mempelajari materi tentang aklak terpuji. Siklus II pertemuan kedua dilaksanakan pada hari kamis tanggal 27 September 2018. Dipertemuan ini masih mempelajari materi tentang aklak terpuji. Selanjutnya Siklus III pertemuan ketiga dilaksanakan pada hari kamis tanggal 4 Oktober 2018. Dipertemuan ini juga masih mempelajari materi tentang aklak terpuji.
Peneliti melakukan rekapitulasi terhadap kinerja guru, aktivitas, dan hasil belajar siswa dari Siklus I, II hingga Silkus III antara lain sebagai berikut:

Tabel 1. Rekapitulasi Kinerja Guru dalam Pembelajaran.

\begin{tabular}{|c|l|l|l|l|}
\hline No & Keterangan & Siklus I & Siklus II & Siklus III \\
\hline 1 & Nilai Perolehan & 70,76 & 81,53 & 90,76 \\
\hline 2 & Kriteria & Baik & Sangat Baik & Sangat Baik \\
\hline 3 & Peningkatan & \multicolumn{4}{|c|}{11,53} \\
\hline
\end{tabular}

Sumber: Hasil Perhitungan

Berdasarkan Tabel diatas diperoleh keterangan pada Siklus I kinerja guru memperoleh nilai 70,76 dengan kategori baik kemudian meingkat pada Siklus II menjadi 81,53 dengan kategori sangan baik kemudian meningkat pada Siklus III menjadi 90,76 dengan kategori sangat baik.

Tabel 2. Rekapitulasi Nilai Aktivitas Siswa Setiap Siklus

\begin{tabular}{|c|l|l|l|l|}
\hline No & Keterangan & Siklus I & Siklus II & Siklus III \\
\hline 1 & Nilai Perolehan & $\begin{array}{l}44 \% \text { sampai } \\
\text { dengan68\%. }\end{array}$ & $\begin{array}{l}\text { 68\% sampai } \\
\text { dengan } 80 \%\end{array}$ & $\begin{array}{l}80 \% \text { sampai } \\
\text { dengan 96\% }\end{array}$ \\
\hline 2 & Kriteria & Baik & Sangat Baik & Sangat Baik \\
\hline
\end{tabular}

Sumber: Hasil Perhitungan

Berdasarkan tabel diatas diperoleh keterangan pada Siklus I nilai aktivitas siswa 44\% sampai dengan 68\%. Dan meningkat pada Siklus II menjadi 68\% sampai dengan $80 \%$. Kemudian meningkat pada Siklus III $80 \%$ sampai dengan $96 \%$.

Menurut Syah Belajar adalah tahapan adalah perubahan prilaku siswa yang relatif positif dan menetap sebagai hasil interaksi dengan lingkungan yang melibatkan proses kognitif. Melalui metoderole playing siswa dapat aktif mengembangkan kemampuan berbicara dan trampil dalam memaknai materi yang dipelajari siswa.

Tabel 3. Rekapitulasi Hasil Belajar Siswa Setiap Siklus

\begin{tabular}{|l|l|l|l|l|}
\hline No & Keterangan & Siklus I & Siklus II & Siklus III \\
\hline 1 & Nilai Perolehan & 73,9 & 79,21 & 83,4 \\
\hline 2 & Kriteria & Baik & $\begin{array}{l}\text { Sangat } \\
\text { Baik }\end{array}$ & $\begin{array}{l}\text { Sangat } \\
\text { Baik }\end{array}$ \\
\hline 3 & Peningkatan & \multicolumn{4}{|c|}{32} \\
\hline
\end{tabular}

Sumber: Hasil Perhitungan

Berdasarkan tabel diatas, dapat diketahui peningkatan nilai rata-rata hasil belajar siswa pada Siklus I, Siklus II dan Siklus III. Pada Siklus I nilai rata-rata 73,9 dan meningkat pada Siklus II menjadi 79,21 dan meningkat pada Siklus III menjadi 83,4

Berdasarkan data-data yang telah diuraikan diatas, diperoleh keterangan bahwa indikator keberhasilan tindakan yang ditetapkan telah tercapai, yaitu terjadi peningkatan aktivitas siswa setiap siklusnya dengan kategori baik dan adanya peningkatan hasil belajar setiap siklusnya, yaitu siswa dianggap tuntas belajar apabila $>75 \%$ dari jumlah siswa mencapai niali dengan kategori baik atau memperoleh nilai minimal $>75 \%$. Dengan demikian, penelitian pada siswa kelas VIII MTsN Kota Bogor Tahun pelajaran 2018/2019 selesai. 


\section{SIMPULAN}

Hasil dalam mata pelajaran Akidah Akhlak meningkat karena strategi Role Playing ini memberikan dampak yang baik terhadap hasil belajar siswa yang mengalami peningkatan yang signifikan berdasarkan pemberian pretest dan posttest, dibandingkan pada kelas kontrol yang menggunakan metode ceramah. Hasil penelitian pembelajaran dengan menggunakan pembelajaran Role Playing dilakukan dengan menggunakan lembar observasi pada setiap siklus untuk mengetahui sejauh mana metode pembelajaran yang diterapkan telah terlaksana sesuai dengan rencana dan harapan peneliti. Dari ketiga siklus yang dilakukan tampak terlihat terjadinya hasil belajar siswa, karena nilai rata-rata tiap siklus selalu meningkat. pada posttest siklus I yaitu 11 siswa $(28,9 \%)$ dengan nilai rata-rata posttest 73,9. Pada posttest siklus II meningkat jadi 20 siswa $(52,6 \%)$ siswa yang mencapai ketuntasan belajar dengan nilai rata-rata posttest 79,4 . Dan pada posttest siklus III terjadi peningkatan lagi menjadi 35 siswa $(92,1 \%)$ yang mencapai ketuntasan belajar dengan nilai rata-rata posttest 83,4. Dengan demikian, melalui metode Role Playing hasil belajar siswa secara umum dikategorikan baik diatas kriteria ketuntasan minimal (KKM).

\section{REFERENSI}

[1] Sa'ud, Udin Syaefudin, dan Makmun Syamsudin Abin, Perencanaan Pendidikan, Bandung: PT Remaja Rosdakarya, 2011.

[2] Sadiman, Arief dan Rahardjo. Media Pendidkan,Jakarta: PT Raja Grafindo Persada, 2011.

[3] Susanto, Ahmad, Teori Belajar \& Pembelajaran di Sekolah Dasar, Jakarta: Kencana, 2013.

[4] Dimyati dan Mudjiono, Belajar dan Pembelajaran, Jakarta: Rineka Cipta, 2012

[5] Usman, Moh. Uzer, Menjadi Guru Profesional, Bandung: PT Remaja Rosdakarya, 2009,

[6] Arikunto, Suharismi dan Suhardjono, Penelitian Tindakan Kelas, Jakarta: Bumi Aksara, 2011.

[7] Abidin Arief, Zainal. Metodologi Penelitian Pendidikan, Bogor: Graha Widya Sakti, 2012. 